\title{
Erratum to: Is low-level laser therapy effective in acute or chronic low back pain?
}

\author{
Saime Ay • Șebnem Koldaș Doğan • Deniz Evcik
}

Received: 30 April 2010 / Accepted: 10 May 2010/Published online: 28 May 2010

(C) Clinical Rheumatology 2010

\section{Erratum to: Clin Rheumatol}

\section{DOI 10.1007/s10067-010-1460-0}

The sentence; "Pain was evaluated by visual analog scale (VAS) and Likert scale." In the Abstract should be replaced by; "Pain was evaluated by visual analog scale (VAS)."

The second sentence; "Patients were treated for $4 \mathrm{~min}$ at each point, producing energy of approximately $40 \mathrm{~J} / \mathrm{cm} 2$ using a $850 \mathrm{~nm}$ gallium-aluminum-arsenide laser" in the Materials and methods is incomplete. The correct sentence is; "Patients were treated for $4 \mathrm{~min}$ at each side, producing total energy of approximately $40 \mathrm{~J}(43.2 \mathrm{~J})$ for both sides of the paraspinal tissues using a $850 \mathrm{~nm}$ gallium-aluminumarsenide laser."

The online version of the original article can be found at http://dx.doi. org/10.1007/s10067-010-1460-0.

S. Ay $(\bowtie) \cdot$ Ş. K. Doğan $\cdot$ D. Evcik

Department of Physical Rehabilitation and Medicine,

Ufuk University School of Medicine,

Ankara, Turkey

e-mail: saimeay@yahoo.com 